\title{
Pós-verdade para quem? Fatos produzidos por uma ciência racista ${ }^{+*}$
}

\author{
Katemari Rosa ${ }^{1}$ \\ Instituto de Física - Universidade Federal da Bahia \\ Alan Alves-Brito ${ }^{1}$ \\ Instituto de Física - Universidade Federal do Rio Grande do Sul \\ Bárbara Carine Soares Pinheirol \\ Instituto de Química - Universidade Federal da Bahia \\ Salvador - BA
}

\section{Resumo}

Este ensaio busca trazer reflexões sobre a construção do sistema de verdades no qual se fundamenta a Ciência Moderna e Contemporânea e, mais especificamente, como o ensino de ciências, que sempre foi pautado numa lógica científica branca que nega o conhecimento produzido por corpos negros, posiciona-se nessa discussão negacionista do "outro". Argumentamos que, no que concerne à própria estruturação da argumentação científica e de seu status quo, a Ciência Hegemônica eurocêntrica e branca - é, por si só, um estado de pós-verdade para pessoas negras e suas epistemologias. As atuais preocupações da comunidade branca de ensino e divulgação de ciências, em relação ao negacionismo científico e à construção de narrativas que negam as produções da ciência branca, desconsideram que esse sempre foi o comportamento que tiveram com as epistemologias negras e os conhecimentos "estrangeiros". Ao longo do texto, trazemos exemplos de conhecimentos que são tidos como fatos objetivos $e$, no entanto, são fatos produzidos por uma comunidade racista e segue sendo reproduzida na educação em ciências, contribuindo com a perpetuação do racismo antinegro em nossa sociedade.

Palavras-chave: Educação em Ciências; Pós-verdade; Decolonialidade; Racismo Científico.

\footnotetext{
${ }^{+}$Whose post-truth? Produced fact by a racist society

* Recebido: junho de 2020. Aceito: setembro de 2020.

${ }^{1}$ E-mails: katemari@gmail.com; alves.brito.a@gmail.com; soarespinheirob@gmail.com
} 


\begin{abstract}
In this essay, we reflect on the construction of this system of truths on which modern and contemporary science is grounded. Specifically, we discuss how science teaching, always guided by a white scientific logic that denies knowledge produced by Black bodies, positions itself in this negationist discussion of "otherness". We argue, as far as the structuring of scientific argumentation and its status quo is concerned, Hegemonic Science - Eurocentric and white - is, in itself, a post-truth state for Black people and our epistemologies. The current concerns from the white science education community, in relation to scientific negativism and the construction of narratives that deny the production of white science, disregard that this has always been the behavior they had with Black epistemologies and "foreign" knowledge. Throughout the text, we bring examples of knowledge that are taken as objective facts are, in reality, produced facts created by a racist community. These produced facts continue to be reproduced in science education, contributing to perpetuate racism in our society.
\end{abstract}

Keywords: Science Education; Post-truth; Decoloniality; Scientific Racism.

\title{
I. Introdução
}

Primeiro, empregada em 1992 (TESICH, 1992), mas eleita em 2016 como a palavra do ano pelo Dicionário Oxford (ENGLISH OXFORD DICTIONARIES, 2016), a pós-verdade tem sido amplamente discutida (e questionada) em vários campos do conhecimento. De acordo com o Dicionário Oxford, o vocábulo pós-verdade está relacionado ao conjunto de circunstâncias em que fatos objetivos são menos influentes na formação da opinião pública do que, por exemplo, o apelo à emoção e às crenças pessoais.

Do ponto de vista da Educação em Ciências, é importante lembrar que o conceito Moderno e Contemporâneo de Ciência ${ }^{2}$ (MATTHEWS, 1995) baseia-se na razão (logos), no seu sentido grego, ou seja, reunir, ligar, calcular, medir, de forma que a razão está implicitamente relacionada ao pensar, opondo-se ao imperfeito, à opinião. E, nesse sentido, é ele, o pensamento, que nos faz ultrapassar as aparências para finalmente chegarmos à realidade (verdade). É nesse contexto que a Ciência Moderna e Contemporânea (CMC) tem sido a responsável pela criação e instauração da verdade universal, em que sujeito e objeto são irreconciliáveis. A CMC surge como um sistema de pensamento que propõe uma

\footnotetext{
${ }^{2}$ No presente artigo, entendemos Ciência como construção humana, historicamente localizada no tempo e no espaço, que foge ao escopo de uma única disciplina, cuja verdade, transitória, não é inquestionável.
} 
compreensão total dos fenômenos, em que tudo parece ordenado, sem contradições e ambivalências.

No entanto, quem são, do ponto de vista da construção e interpretação histórica da CMC e dos seus processos de educação e divulgação, os sujeitos/pessoas que pensam e organizam as verdades científicas? Seria o prefixo "pós-", tão popular nos últimos anos, apenas uma expressão que alude à instauração de um período que vem depois de uma determinada situação (verdade, em nossa discussão) ou seria esse prefixo a marca de superação de uma particularidade e, mais do que nunca, o anúncio de uma era, de um estado de coisas, que apenas reafirma sistemas históricos de exclusão e epistemicídio? Quem são, de fato, ao longo da História da Ciência, as pessoas que têm tido o direito (autoridade) de falar (SPIVAK, 2010) de/sobre Ciência e, mais importante, ter acesso aos bens culturais materiais e simbólicos que ela promove?

Dito isso, buscaremos ao longo do presente ensaio trazer reflexões sobre de que forma o sistema de verdades, base da CMC, se constrói e, mais importante, como o ensino de ciências, que sempre foi pautado numa lógica científica branca que nega o conhecimento produzido por corpos negros, posiciona-se nessa discussão negacionista do "outro". Argumentamos que, no que concerne à própria estruturação da argumentação científica e de seu status quo, a Ciência Hegemônica - eurocêntrica e branca — é, por si só, um estado de pós-verdade para pessoas negras e suas epistemologias. As atuais preocupações da comunidade branca de ensino e divulgação de ciências, em relação ao negacionismo científico e à construção de narrativas que negam as produções da ciência branca, desconsideram que esse sempre foi o comportamento que tiveram com as epistemologias negras e os conhecimentos "estrangeiros" (FANON, 1961). Defendemos que essa mesma comunidade cria uma falsa coletividade nos objetivos do ensino e divulgação de ciências e espera que docentes e divulgadoras negras e negros saiam em defesa dessa ciência tradicional, historicamente racista.

De maneira mais específica, no escopo do que se propõe essa coletânea, cabe-nos então perguntar: é, de fato, a pós-verdade, um fenômeno decorrente da crítica à ciência moderna construída por estudiosos nos séculos XX e XXI ou ela, como um sistema de crenças pronto para deslegitimar o pensamento de, por exemplo, alteridades negras, sempre existiu? Como as discussões que problematizam a universalidade e a hegemonia branca cientifica nos ajudam a pensar o conceito contemporâneo de pós-verdade? Quais são os aspectos políticos que permeiam a questão da pós-verdade na educação e divulgação das Ciências nesse contexto das alteridades subalternizadas? Quais são as implicações politicas de uma educação científica comprometida com a reflexão sobre o sistema excludente de pósverdade?

A seguir, trazemos elementos que podem ajudar a responder essas questões. Inicialmente, propomos uma discussão sobre as relações entre a racionalidade científica "moderna" e a construção do racismo. Em seguida, a partir de referenciais decoloniais, 
contrapomos a própria ideia de modernidade, introduzimos o conceito de epistemicídio e problematizamos as noções de epistemologias dominantes/insurgentes. Por fim, centramos a discussão na comunidade em educação e divulgação científica brasileira nesse contexto em que questionamos uma suposta era de pós-verdade.

\section{A construção do racismo}

A Histórica da Ciência, em seus processos teóricos e metodológicos modernos e contemporâneos, dá conta de que a Ciência é uma construção humana, coletiva, bem localizada no tempo e no espaço, não apenas submetida a fatores internos, mas, principalmente, externos, altamente dependentes de aspectos econômicos, políticos, sociais e culturais (LIGHTMAN, 2016). No entanto, é importante ressaltar que, ao longo dos anos, cientistas, educadoras, educadores e pessoas que divulgam ciências têm pouco debatido ou problematizado como as ciências e as tecnologias modernas têm fomentado o conceito de raça $^{3}$ e o racismo. Nesse esquema, as pessoas negras e os povos originários têm sido renegados do processo de construção da modernidade, ontologicamente, epistemologicamente e teologicamente (MUNANGA, 2019).

Historicamente, a Educação em Ciências do presente século é fortemente baseada nos princípios da Revolução Científica (1543-1687), pensada como um conjunto de transformações culturais, sociais e filosóficas que marcaram o início da Era Moderna, amplamente pautada no discurso da razão e da verdade (ANDERY, 2012). Além disso, ao proporem uma nova concepção do Universo que representava a ruptura com o pensamento escolástico medieval e o pensamento antigo greco-romano, a Física e a Astronomia desenvolveram, em particular, papéis marcantes no estabelecimento das bases teóricas e epistemológicas da assim denominada Revolução Científica. Ou seja, no âmbito do mundo europeu branco, o modelo geocêntrico de Ptolomeu, aceito como conhecimento válido por cerca de 12 séculos, foi substituído pelo modelo heliocêntrico de base copernicana. Acontece que para além das mudanças e concepções cosmológicas, intrinsecamente, meio à Revolução Científica, ocorre a disputa sobre o que é conhecimento, entendido como ciência e, crucialmente, quem é que pode compor, propor e constituir essa ciência; um debate que nos acompanha até a atualidade (LIGHTMAN, 2016).

No entanto, vale à pena frisar que é também no bojo dessas transformações culturais e científicas, a partir do século XV, que acontece a expansão da Europa Ocidental e, por meio dela, a colonização do "outro" não europeu - africanos e americanos - a priori subalternizado, desumanizado de sua própria existência, potência e capacidade de pensar. Nesse sentido, podemos afirmar que a construção moderna do racismo se dá com base no

\footnotetext{
${ }^{3} \mathrm{O}$ conceito de raça que operamos no presente artigo tem, primordialmente, uma conotação política, baseada em efeitos desiguais de hierarquização e de mobilidade social-intelectual, uma vez que raça, como conceito biológico/genético, não se sustenta cientificamente. Como marcador social da diferença atua, no entanto, na intersecção com outras categorias, distribuindo privilégios e capilaridades epistêmicas.
} 
projeto europeu de colonização do mundo, impulsionado pelos conhecimentos da Astronomia vigente e das tecnologias criadas no âmbito das Grandes Navegações, em que, de um lado, estavam os colonizadores superiores e, do outro, os colonizados naturalmente inferiores. Amparados pelo discurso científico, os europeus não apenas expandiram mercados, mas também desapropriaram corpos, sedimentando o pensamento científico moderno com vieses de raça. Além disso, a construção moderna do racismo também se valeu do domínio histórico europeu ao terem criado o não lugar, o não estar no mundo, totalmente reservados aos corpos (e pensamentos) subalternizados negros. No imaginário social, histórico e científico dos europeus que chegaram aos "novos mundos" ("velho" e "novo" na lógica colonizadora), impulsionados por seus conhecimentos e tecnologias, os negros eram desprovidos de pensamento, representados como pessoas de um só olho, sem cabeça e com chifres, com características fenotípicas marcantes como a morfologia da cabeça, a cor da pele, a textura de cabelo, a forma do nariz e dos lábios. Por conta dessas características os negros tinham que ser cientificamente inferiores (MUNANGA, 2019).

O conceito de raça, portanto, é criado durante o colonialismo, em que europeus passam a classificar os povos colonizados como sendo de outra raça, seres inferiores, menos humanos e pautam as raças através de características fenotípicas: aquelas pessoas que não tinham as características semelhantes às do colonizador, eram racializadas, enquanto o colonizador é o padrão a que se deve comparar, é o universal, o superior (QUIJANO, 2005). Tudo o que é relacionado ao colonizador, ao europeu, é positivo, civilizado, racional e científico. Em contrapartida, os povos colonizados são primitivos, irracionais, anticientíficos, são os Outros. Atrelado a isso, surge o conceito de eurocentrismo ${ }^{4}$ também com suas fundações nos processos coloniais em que a Europa se coloca como o centro das relações econômicas, culturais e intelectuais do mundo.

Tais ideias racistas foram ainda mais sedimentadas por meio da impetuosidade da Europa Iluminista do século XVIII em busca da classificação sistemática de minerais, flores e animais, incluindo os seres humanos, projeto esse fortalecido e amparado nas ideias e no trabalho do cientista Carl von Linné (1707-1778), um dos mais proeminentes e influentes cientistas da época. Linné pretendia elaborar um sistema de classificação que fosse realmente novo que, tendo a América hispânica como um laboratório interracial, esse sistema deveria ser universalizado com base na definição moderna de ciência e do "método científico" (observação, coleta, análise e classificação). No entanto, Linné foi dominado pelo olhar etnográfico de superioridade, cujo trabalho, altamente baseado em estereótipo, tornou-se, talvez, a pedra angular para o desenvolvimento do racismo cientifico moderno, dominante nos

\footnotetext{
${ }^{4}$ Stricto sensu, o termo Eurocentrismo que aqui empregamos está não apenas diretamente vinculado ao seu contexto usual, a saber, ultravalorização epistêmica dos europeus e seus descendentes na lógica capitalista e neoliberal moderna, mas, também, intrinsecamente ligado aos processos de dominação nas lógicas coloniais modernas do ser, saber e poder que funcionam, na atualidade, como práticas educativas hegemônicas. Ou seja, há uma perspectiva histórica e contemporânea, ressignificada, no Brasil, no contexto das tensões e disputas "raciais".
} 
séculos XVIII e XIX, sendo contestado completamente pela genética no século XX (BETHENCOURT, 2018) mas que, mesmo sendo uma pseudociência, ainda está na base do racismo estrutural à brasileira, que é predominantemente um racismo de marca, com fortes implicações em políticas públicas de educação, cultura e divulgação de ciências (ALVESBRITO, 2020).

As bases modernas do racismo são também fortemente justificadas e amparadas na Filosofia. Por exemplo, vale destacar que o filósofo alemão Immanuel Kant (1724-1804), autor de A Crítica da Razão Pura (1781), considerada uma das mais influentes obras na História da Filosofia - e, pelo seu idealismo, ao lado de "penso, logo existo" de René Descartes (1596-1650), uma das bases filosóficas da CMC europeia - era defensor voraz da ideia de que havia diferenças hereditárias de raça, reproduzindo preconceitos históricos contra as pessoas negras, no que diz respeito, por exemplo, aos odores e suas estruturas de organização do pensamento (BETHENCOURT, 2018). Kant busca o tempo inteiro não apenas destacar a estreita relação que havia entre a racionalidade neutra e universal e a Europa mas, também, explicar e interpretar o jeito "puro" de se fazer filosofia numa relação direta com a "brancura", associada materialmente e culturalmente à Europa.

Dessa forma, argumentamos que a concepção moderna de ciência, que, em última instância, define direcionamentos teóricos, pedagógicos e epistêmicos da Educação em Ciências, é, toda ela, baseada num sistema complexo em que as pessoas brancas (europeias) são tratadas como condição humana normativa e universal, enquanto o ser negro, o "outro", precisa de uma explicação científica para estar no mundo. No Brasil, como se sabe, teorias eugenistas foram cientificamente amparadas por discursos de pessoas das ciências, da filosofia, da educação e da antropologia e políticas públicas de embranquecimento da população foram colocadas em prática (SCHWARCZ, 2014). Além disso, desde o pósabolição, diferentes políticas/medidas públicas também têm negado às pessoas negras o acesso à cultura, à educação e à divulgação em ciências o que, parcialmente, explica a subrepresentação de pessoas negras em carreiras científicas e tecnológicas no Brasil do presente século (ANTENEODO et al. 2020).

Outro aspecto fundamental no processo de entendimento do surgimento do racismo moderno é pensar que o Iluminismo (ANDERY, 2012), como proposta autodeclarada de humanização do mundo com base na ciência, falhou, deixando as pessoas negras na condição de sub-humanas, de não humanas, como se pode inferir por meio das ideias racistas de alguns de seus mais importantes filósofos — Buffon (1707-1788), Helvétius (1715-1771) e Voltaire (1694-1778) —, como bem reportado por Munanga (2019). As ideias Iluministas são também basiladoras da $\mathrm{CMC}$ e fundamentais para o aprofundamento do pensamento moderno que exclui corpos e mentes negras dos processos de produção e elaboração de conhecimento válido atual. Novamente, chamamos a atenção para o fato de que a Física e a Astronomia, consideradas pelos Iluministas como "ciências mãe", são fundamentais para a materialização e a definição da Cosmologia Moderna e Contemporânea. A Física, em particular, é 
denominada como "verdadeira filosofia" pelos Iluministas. Tanto a Física quanto a Astronomia são assertivas na construção epistêmica e metodológica do fazer ciência tão propalado na atualidade em Educação e Divulgação de Ciências. Além disso, a Física, por meio da Termodinâmica, indispensável para a Revolução Industrial, tem papel crucial no desenvolvimento do Capitalismo que, por sua vez, desapropria os corpos negros, uma vez mais, do lugar de pensamento, subjugando-os e condicionando-os ao lugar de mercadoria, de mão de obra do capital. O racismo, como estrutura, é, portanto, uma tecnologia social de poder que impede que os corpos negros se desenvolvam em suas potencialidades, sobretudo as científicas.

No entanto, embora invisibilizados nos estudos Históricos e Filosóficos das Ciências, principalmente no âmbito da Educação em Ciências e/ou Ensino de Astronomia/Física/ Química, os quais têm sido historicamente enviesados pelas ideias do colonialismo da Europa e do imperialismo dos Estados Unidos, são várias as/os intelectuais que não apenas questionam a lógica racista da ciência moderna de base colonial/imperialista como também explicam como essas funcionam.

Em a Crítica da Razão Negra (2014), livro escrito em contraponto à Crítica da Razão Pura de Kant, Achille Mbembe, um dos mais destacados pensadores negros da atualidade, ressalta que embora o capitalismo deseje reduzir os corpos negros a coisa e mercadoria, num fetichismo do dinheiro, o próprio corpo negro torna-se símbolo de desejo consciente de vida, força engajada no ato de criação. Em se tratando do pensamento europeu, Mbembe defende que esse "sempre teve a tendência para abordar a identidade não em termos de pertença mútua (co-pertença) a um mesmo mundo, mas antes na relação do mesmo ao mesmo, do surgimento do ser e da sua manifestação no seu ser primeiro ou, ainda, em seu próprio espelho" (MBEMBE, 2017, p. 10). E, nesse sentido, segue ele:

o Negro e a raça têm significado, para os imaginários das sociedades europeias, a mesma coisa. Designações primárias, pesadas, perturbadoras e desequilibradas, símbolos de intensidade crua e de repulsa, a aparição no saber e no discurso moderno sobre o homem (e, por consequência, sobre o "humanismo" e a Humanidade) foi, se não simultâneo, pelo menos paralelo; e, desde o início do século XVIII, constituiu, no conjunto, o subsolo (inconfessado e muitas vezes negado), ou melhor, o núcleo complexo a partir do qual o projecto moderno de conhecimento - mas também de governação - se difundiu (MBEMBE, 2017, p. 10).

Cheick Anta Diop (1923-1986), também um dos maiores pensadores negros do século XX (ALVES-BRITO et al. 2020), já denunciava o racismo da ciência moderna com base europeia. Ele enfrentou a visão eurocêntrica da ciência que colocava a África num lugar de subalternidade. Diop é reconhecido na História da Ciência como um dos principais responsáveis pelo fortalecimento e valorização do legado científico, cultural, material e simbólico dos povos africanos. Foi um defensor crítico da descolonização do pensamento e reafricanização da realidade, construindo uma visão positiva das epistemologias africanas, 
completamente baseado no rigor lógico e no diálogo e articulação de temas que extrapolavam as fronteiras de uma única disciplina. Estudante de doutorado de Gaston Bachelard (18841962), foi ele mesmo vítima do pensamento racista europeu ao não ter o seu trabalho de doutorado reconhecido como contribuição de alto rigor científico, porque assegurava que os povos do Egito eram negros, contrário ao que foi escrito pela narrativa histórica europeia. Diop e outros pensadores afrocentristas já defendiam que "a humanidade começou na África e todos os subgrupos ou variedades humanas contemporâneos, isso é "raças", são ramificações da árvore genealógica na África [...].” (FINCH III, 2009, p. 174), fato esse que vem sendo ratificado pela ciência "branca" moderna e contemporânea.

Marimba Ani, uma das mais importantes intelectuais negras do nosso tempo é crítica voraz do pensamento e da cultura europeia, faz contribuições valiosas para a compreensão da cultura e da personalidade europeia como expressão de poder e domínio. Para Ani, uma questão de pesquisa fundamental a saber e que ainda estrutura o pensamento científico moderno é entender "qual a explicação para o poder europeu e seu sucesso no domínio do mundo?" (ANI, 1994). Para ela, o pensamento europeu, de base racista, pode ser caracterizado por meio de três palavras em língua africana - asili (essência cultural), utamawazo (pensamento culturalmente estruturado) e utamaroho (personalidade coletiva dos seus membros):

$O$ asili é a semente que produz a força. A força é o utamaroho de um povo. É a personalização coletiva do asili e representa a possibilidade de sua existência continuada. O utamawazo é a modalidade de pensamento em que a vida mental do povo deve funcionar para que eles possam criar e aceitar uma cultura que seja consistente com a asili originária. Utamaroho e utamawazo são fenômenos extremamente fortes na experiência Européia. Eles estão reunidos na asili, o princípio raiz da cultura. Nem o caráter do utamaroho Europeu nem a natureza de seu utamawazo são modificáveis, a menos que a própria asili mude. Entenda desta maneira, a cultura é o desdobramento de princípios já implicados em seu processo originário. Mas o conceito Asili não implica a sua própria causa (ANI, 1994, p. 16).

Para Ani, o povo europeu, por meio do racismo, consegue estabelecer o seu domínio transformando negros em objetos, dessacralizando-os. Sujeito (racional) e objeto (irracional) estão, para ela, separados no contexto do pensamento moderno europeu e, a razão, separada da emoção. Dessa forma, os europeus se constituem eles mesmos em seres superiores, controladores, dominadores da razão e, dessa forma, justificam a escravidão, que é a materialidade do racismo. Para ela, o projeto de domínio, subalternização e invisibilização de corpos negros e dos subalternizados no sistema colonizador da Europa se deu, sobretudo, por meio da educação. Emblemático, assim, pensarmos na realidade brasileira que, do período colonial aos nossos dias, a educação continua sendo a ferramenta de controle e de poder dos pensamentos hegemônicos. A efetivação, por exemplo, em Educação em Ciências, das Leis 
$10.639 / 2003$ e 11.645/2008, as quais estabelecem as diretrizes e bases da educação nacional para incluir em todos os níveis do currículo da educação básica e superior a obrigatoriedade do ensino da História e da Cultura Africana, Afro-Brasileira e Indígena é uma demonstração explícita de como se dá o racismo à brasileira na educação e divulgação de ciências. Convivese com a ideia da depreciação do legado africano à cultura brasileira e sob o domínio do ilusório mito da democracia racial (MUNANGA, 2019).

Como, então, rompermos com essas correntes históricas que têm colocado as pessoas negras em lugar de subalternidade e fortalecido sistemas de crenças, num estado permanente de "pós-verdade", que deslegitima o pensamento das pessoas negras? Nesse sentido, Achille Mbembe nos provoca:

Sendo o Negro e a raça duas figuras centrais (ainda que negadas) do discurso euroamericano sobre o "homem", será possivel pensar que a desclassificação da Europa e a sua consequente inscrição na categoria de simples província do mundo determinará a extinção do racismo? Ou deveremos pensar que, se a humanidade se tornar fungivel, o racismo vai reconfigurar-se nos interstícios de uma nova linguagem - assoreada, molecular e fragmentada — acerca da "espécie"? Se colocamos a questão nesses termos, não corremos o risco de esquecer que o Negro e a raça nunca foram elementos congelados (MBEMBE, 2017, p. 18).

Em Os Condenados da Terra (1961), Frantz Fanon (1925-1961), uma das principais referências para se pensar o efeito devastador da colonização sobre a saúde psíquica de povos subalternizados, aborda não apenas o processo histórico de descolonização do qual ele mesmo, intelectual martinicano, teve que experimentar ao se dar conta, na França, de que nunca tinha sido um francês como assim o pensava, mas revisita a teoria marxista a partir da realidade colonial e sua divisão entre raças. O livro traz a materialidade violenta dos processos coloniais e a violência implícita que o processo de descolonização também implica.

\section{Epistemologias decoloniais}

Corriqueiramente, ao tratarmos do conhecimento científico, aquele brancocêntrico ocidental, acessamos unicamente bases ontológicas gregas que buscam legitimar uma base gnosiológica eurocêntrica. Entretanto, ao partirmos de uma compreensão pluriversal da ciência, é necessário trazer as diferentes cosmogonias a exemplo das africanas, que estão no cerne constitutivo humano. Assim, nos resta pensar que o "Milagre Grego" se trata de um mito moderno europeu que tem como intuito criar marcos fundacionais não só para as bases do pensamento "ocidental" que é também universalizado, mas principalmente para demarcar premissas de racionalidade e de modo de produzir conhecimento a partir de si, desconsiderando ou reduzindo tudo aquilo que estiver fora desse escopo ou por conteúdo ou por forma ou por cosmovisão. 
Além da civilização grega, podemos destacar na antiguidade a existência de vários outros grandes povos, como os fenícios, sumérios, os chineses, os maias, os astecas, os incas, os romanos, os egípcios, entre outros. No caso específico do continente africano que, no referido período, não era um continente e não se tinha essa noção atual de um todo homogêneo, existiram muitos outros impérios além de Kemet (como os povos africanos chamavam o antigo Egito), como, por exemplo, Axum, Meroé, Núbia, Numídia, a Terra de Punt, o Império de Kush, o Império Ashanti e o Império de Gana, Daomé, dentre outros. Vale destacar que Kemet, ao contrário do que muitos pensam, não fica na Europa, mas trata-se de uma civilização africana e negra (DIOP, 1983).

Uma breve leitura da história nos mostra que o Antigo Egito (3200 a.C - 332 d.C) tem origem bem anterior à da Grécia antiga (1200 a.C - 529 d.C) e que a própria humanidade surge no continente africano ${ }^{5}$. Como imaginar que esses povos se mantiveram improdutivos material e intelectualmente por milênios e que só merecem um capítulo na história da humanidade a partir do episódio macabro da diáspora africana escravagista, traduzido por nós como a desumanização, o genocídio e o sequestro humano (de seus corpos e de suas memórias)?

Infelizmente, é muito comum em nosso país, jovens em geral terem acesso à história da população africana no mundo apenas a partir do tráfico de seres humanos escravizados (MUNANGA; GOMES, 2006), comumente chamados de "escravos", um termo profundamente equivocado, pois remete a uma vinculação ontológica, a uma condição de existência. No entanto, pessoas não nascem escravas, elas são escravizadas.

Desde o início do processo colonial, difundiram-se imagens estereotipadas e redutoras das pessoas que foram escravizadas, reificando-as na função de escravo/coisa, ecoando aquilo que Achile Mbembe (2018, p. 12) ressalta acerca do tráfico atlântico no qual "homens e mulheres originários de África foram transformados em homens-objeto, homensmercadoria e homens moeda".

A racionalidade europeia efetivou a leitura oficial da história da humanidade levando em conta somente a experiência daquele continente e universalizando reflexões alheias às múltiplas possibilidades do conhecer (QUIJANO, 2005). A história tem uma direção, um sentido único em direção ao progresso, à modernização. Tudo que é assimétrico em relação a esse avanço e desenvolvimento é entendido como atrasado, subdesenvolvido, primitivo. Segundo Adichie (2018) e Dussel (1993), essa universalização da história é um dos vários mitos da modernidade, e faz-se necessário desconstruirmos tais perspectivas visando não só o cumprimento da Lei de Diretrizes e Bases da Educação Nacional, assim como das legislações específicas, a exemplo das leis 10.639/2003 e 11645/2008, mas fundamentalmente resgatar narrativas, produções intelectuais e referências positivas ancestrais.

\footnotetext{
${ }^{5}$ A Arqueologia e a Paleontologia nos apontam que o fóssil humano mais antigo encontrado na terra possui cerca de 300 mil anos e foi achado em escavações realizadas no leste do continente africano, atual Marrocos.
} 
Abdias Nascimento, em O Genocídio do Negro Brasileiro (2016), é certeiro ao apontar para o branqueamento cultural como uma das dimensões do genocídio da população negra no Brasil. Já na década de 70 do século passado, no contexto da ditadura militar, Nascimento (2016) atrelava ao extermínio físico da população negra o embranquecimento cultural, o genocídio cultural e epistêmico, como a face oculta desse processo letal. Neste ponto, Abdias reconhece brilhantemente a estreita e íntima relação entre a modernidade capitalista e a racionalidade do extermínio colonialista dos povos subalternizados. De acordo com Njeri (2019), é o genocídio histórico e contemporâneo global que age contra a saúde física e mental dos povos africanos e africanos em diáspora, afetando-os em todas as áreas de suas vidas: espiritualidade, herança, tradição, cultura, agência, autodeterminação, casamento, identidade, ritos de passagem, economia, política, educação, arte, moral e ética. Desta forma, os africanos sofrem o trauma histórico da sua desumanização e reproduzem as violências, contribuindo - e muitas das vezes facilitando o trabalho - para o genocídio.

Os agentes da colonização não somente recorreram a estratégias de genocídio epistêmico (NASCIMENTO, 2016) ou epistemicídio (SANTOS; MENESES, 2010), mas principalmente sequestraram conhecimentos de povos africanos, ameríndios e asiáticos, incorporando-os no seu escopo cultural imaterial ocidental. Para Aimé Césaire na obra Discurso sobre el Colonialismo (2006), o ato de colonizar não é nem evangelização, nem extensão de Direito. Césaire deixa evidente que a colonização é necessariamente um ato de pilhagem (CÉSAIRE, 2006), uma pilhagem epistêmica (FREITAS, 2016). É unicamente a partir do entendimento de que o processo colonial é um saque, um sequestro, e não apenas um apagamento, que podemos iniciar um processo de resgate histórico dos sujeitos que foram silenciados nesse caminho. O fato de ser a pilhagem, o roubo, a base na qual deitam todas as pretensas justificativas da necessidade da colonização é o argumento essencial para o desenvolvimento da ideia de que precisamos resgatar os conhecimentos que são nossos, as produções ancestrais do nosso povo.

A noção de decolonialidade parte da premissa da negação da colonialidade. O pressuposto aqui defendido é que deixamos de ser colônia de Portugal em 1822, mas os padrões de colonialidade permanecem fortes em nossa vida cotidiana até os dias de hoje. A colonialidade é conceituada por Aníbal Quijano como o padrão de poder criado pelo "colonizador"6 para controlar a subjetividade dos "povos colonizados" (QUIJANO, 2005).

A grande socióloga brasileira Lélia Gonzalez busca analisar a influência da relação entre colonizado e colonizador na construção subjetiva de mulheres negras. Ela afirma que "o colonizado é aquele que não é sujeito do próprio discurso, na medida em que é falado pelos outros" (GONZALEZ, 1988, p.134). Da mesma forma, mulheres, negros, negras e os povos originários são falados e definidos a partir de um sistema ideológico específico. Esse lugar definido a partir desse sistema de hierarquias nega o direito desses sujeitos não só de falarem

\footnotetext{
${ }^{6}$ Essa perspectiva de colonizador e colonizado segue a narrativa do dominante, talvez povos africanos não chamassem os europeus de colonizador, talvez de assassinos, de sequestradores, dentre outros.
} 
por si próprios, mas também de serem sujeitos de sua própria história. Gonzalez destaca que "exatamente por termos sido falados, infantilizados (...) que assumimos a nossa própria fala" (GONZALEZ, 1988, p. 225).

Junto com o importante conceito de infantilização da negritude trazido pela referida socióloga, que remete a uma tutela permanente da luta histórica de pessoas negras por pessoas brancas, está o conceito que emerge do seu pensamento decolonial, a categoria "amefricanidade". Lélia Gonzalez questionava a latinidade das Américas por reconhecer a influência de elementos africanos e ameríndios na construção cultural da região. Dessa forma, a latinidade seria uma ferramenta eurocêntrica para apagar as influências africanas e ameríndias nas construções das Américas (GONZALEZ, 1988); ela propõe, então, uma reinterpretação das experiências de negros e negras no continente americano. Segundo Lélia Gonzalez, a categoria, para além da questão geográfica, "incorpora um processo histórico de intensa dinâmica cultural de adaptação, resistência, reinterpretação e criação de novas formas, que é afrocentrado" (GONZALEZ, 1988, p.77). A Améfrica, ainda segundo Lélia (1998), é uma criação nossa e de nossos antepassados no continente em que vivemos, inspirados em modelos africanos. Fomos historicamente, socialmente e intelectualmente constituídos por povos africanos desde antes da escravidão negra nas Américas, e, por causa disso, somos um povo verdadeiramente "amefricano".

Aprendemos desde criança e passamos nossa vida inteira chamando a Europa de "o velho mundo" (mesmo sabendo que a humanidade surgiu na África). Quando viajamos para a Europa, dizemos que vamos ao berço das civilizações (mesmo sabendo que no mundo existem civilizações anteriores), propagamos a noção de que a universidade surge na Europa, em Bolonha (uma fácil busca no Google nos revela que a primeira universidade do mundo é a universidade de Al-Karaouine em Fes no Marrocos, Leste africano). Além disso, julgamos que europeus são mais avançados e civilizados a ponto de que nossos doutorados sanduíche e nossos pós-doutorados corriqueiramente precisam ser feitos na Europa, mesmo que seja uma temática profundamente endógena e com grandes centros de referência no Brasil. Por último, acreditamos que a Europa é o padrão de ciência e intelectualidade. Assim sendo, todo fenótipo fora do padrão europeu (a exemplo de pessoas negras e indígenas) é caracterizado como não desenvolvedor de ciência, mas de conhecimentos populares, de não-intelectual, mas destinado a trabalhos braçais. Esses são alguns dos vários padrões de colonialidade que atualmente estão fortemente presentes em nossas vidas. Mas de onde vem essa forma de pensamento?

A colonialidade, que é articulada à construção do conceito de raça, se manifesta em três dimensões, a saber: a colonialidade do ser, do saber e do poder (QUIJANO, 2005; FANON, 1961). A colonialidade do ser parte da modulação da existência dos indivíduos. A colonialidade do ser é a dimensão ontológica da colonialidade que se afirma na violência da negação do "outro" (CARNEIRO, 2005), é decorrente do eurocentrismo moderno, eminentemente antropocêntrico, produtor de estereótipos e definidor de critérios de 
humanidade. Por sua cor e raízes ancestrais, os seres diferentes do padrão europeu ficam marcados pela inferiorização, subalternização, desumanização, pela não-existência, sendo tornadas invisíveis suas racionalidades e a dignidade de sua humanidade. Então, a colonialidade do ser se consolida através da violência ontológica projetada para destruir imaginários, identidades, sentidos, existências (MELO, 2019). O conceito de África, por exemplo, foi uma construção da modernidade em que se procurou legitimar através da inferiorização deste continente o projeto colonialista (MUDIMBE, 1988).

Para Fanon (2008), o negro é uma construção do branco. A branquitude europeia, em um dos variados mitos da modernidade, inventou a noção de raças, criando graus hierárquicos entre elas e, inclusive, retirando a humanidade desse "outro" forjado no caldeirão colonial moderno. Criou-se não só a noção de raça negra como aquela atrasada, isenta de características humanas, sexualizada e animalizada, apagando toda a memória desses povos de grandes inventos e grandes impérios, sendo eles reduzidos a esse lugar, ou melhor, a esse não-lugar. A branquitude construiu seus padrões de superioridade, bem como inventou um padrão de subalternidade e subserviência negro, que até os dias de hoje marca nossas construções psíquicas acerca de quem somos, de onde viemos e do que podemos vir a ser. "Por mais dolorosa que possa ser esta constatação, somos obrigados a fazê-la: para o negro, há apenas um destino e ele é branco" (FANON, 2008. p. 28). Hannah Arendt (1998), em sua interpretação acerca do colonialismo/imperialismo europeu no processo de colonização do continente africano no século XIX, serve para ilustrar a narrativa do racismo colonial. Primeiro, por fundamentar como o imperialismo inventou a separação entre o "Eu civilizado" e o "Outro selvagem" através de uma visão única da história. Depois, por se tratar de uma explicação que tem por finalidade reproduzir os ideários de subordinação através de uma hierarquização racial.

No âmbito da colonialidade do poder, Quijano (2005) nos aponta para as relações de poder construídas a partir do projeto da colonização europeia na América, que articulou o colonialismo imperial e a ciência ocidental, através da ideia de raça como instrumento de classificação hierárquica e controle social. Na colonialidade do poder, a raça superior, constituída de homens brancos, cristãos, europeus, tem direito à dominação e as demais raças inferiores são subjugadas.

A colonialidade do saber, por sua vez, impõe o saber europeu como marco referencial de conhecimento verdadeiro e avançado frente a todos os outros tipos de conhecimento que são tomados como inferiores, desconsiderando assim a existência de outras racionalidades e formas de conhecer e interpretar o mundo. Dessa maneira, a ciência moderna tem a concessão do monopólio da distinção universal entre o verdadeiro e o falso. A ciência moderna, transformada em único conhecimento válido e, portanto, enquadrando tudo aquilo que está fora do limite do rigor científico como ignorante, trata-se de um saber que se coloca como modelo, que tem suas bases no eurocentrismo como monopolizador da razão, operando 
pela violência epistêmica e gerando uma subalternização de saberes outros, calcados em lógicas distintas.

\section{Pós-verdade e a comunidade de educação científica brasileira}

A partir de uma compreensão sobre a construção do racismo antinegro, do papel da ciência eurocêntrica nessa construção, dos conceitos de colonialidade, pilhagem epistêmica, partimos para uma discussão de como a comunidade de educação e divulgação científica tem se construído e posicionado em relação ao que valoriza como corpo de conhecimento legítimo.

Em meados de março de 2020 a academia brasileira começou a parar, pelo menos em relação às aulas e a possibilidade de se frequentar os espaços físicos das instituições de ensino superior e centros de pesquisa. Para o povo brasileiro, março marcou o início mais concreto da pandemia do novo coronavírus (COVID-19; do inglês, coronavirus disease 2019). Ao final daquele mês, o antropólogo, sociólogo e filósofo francês, Bruno Latour, publicou um artigo na revista AOC (Analyse Opinion Critique) em que, face à pandemia, questiona as (im)possibilidades do sistema econômico, a globalização e os sistemas de produção. Ao final do texto, Latour propõe um exercício prático composto de seis perguntas para que pensemos em um mundo pós-pandemia.

O texto de Latour circulou em diferentes listas de email da comunidade acadêmica, as perguntas puderam ser vistas também em diversas publicações e grupos em redes sociais. Em nossa bolha social (SANTAELLA, 2018) acadêmica, várias pessoas pareciam querer, como sugere Latour, "utilizar o tempo de confinamento imposto para descrever, primeiro cada um por si, depois em grupo, a que estamos apegados; ao que não estamos prontas para nos libertar; as cadeias que estamos prontas a reconstituir e aquelas que, por nosso comportamento, estamos decididas a interromper" (LATOUR, 2020). Esses questionamentos partem de alguns pressupostos, como o de que podemos estar em confinamento, de que há tempo livre nesse período e de que haverá futuro.

Várias das respostas nos diferentes grupos de colegas da academia falavam sobre as vantagens de haver menos congestionamento de automóveis nas ruas, reuniões online que ficaram mais curtas e objetivas ou projetavam a ruína do modelo capitalista de sociedade, com o argumento de que a produção e o consumo haviam parado durante a pandemia. Parece haver, nesses discursos, uma desvinculação da realidade ou uma compreensão de que a realidade individual é referência para a maioria das pessoas em nosso país. As discussões em torno das provocações de Latour materializam os processos de invisibilização de grande parcela da população brasileira. Afinal, confinamento, tempo e livre e futuro não são aspectos presentes e garantidos para as empregadas domésticas, em maioria mulheres negras. Não é por acaso que o primeiro caso oficial de óbito no Rio de Janeiro, devido à COVID-19, tenha sido de uma mulher negra, empregada doméstica que, forçada a continuar trabalhando, portanto não confinada e sem tempo livre, foi contaminada por sua empregadora, que havia 
contraído o vírus durante viagem na Europa. Para essa empregada doméstica, tampouco há futuro. A invisibilização se dá, também, na omissão do nome dessa empregada em matérias sobre o assunto (eg. G1RIO, 2020). A imprensa, assim como as pessoas da nossa bolha social acadêmica que lêem Latour, costumam esquecer e esconder as vivências de grupos historicamente subalternizados.

Não foi apenas nesse contexto de pandemia que o antropólogo francês influenciou a comunidade de Educação em Ciências, seus trabalhos vêm propondo questionamentos à nossa área há décadas, especialmente no que se refere aos mecanismos de construção da ciência e sua pretensa objetividade. Ao estudar a dinâmica de trabalho de cientistas, utilizando métodos da antropologia, questionou quão objetivas são as escolhas que fazemos ao produzir ciência, desvelou a política de publicação de artigos (LATOUR; WOOLGAR, 1997) e contribui para os estudos sobre a natureza da ciência. Ao argumentar que os fatos científicos eram produzidos, Latour contribuiu, mesmo que não intencionalmente, para subsidiar discursos que questionavam a realidade e colocavam as verdades científicas em cheque. Assim, os debates ocorridos naquela época podem ser lidos como precursores da chamada era da pós-verdade que, mais do que questionar realidades, "fabrica" fatos.

Enquanto o argumento de "fabricação dos fatos científicos" de Latour se mostra como uma questão válida e benéfica para discussão na Educação Científica, os discursos dessa nova era da pós-verdade são vistos como prejudiciais e que devem ser combatidos. Para a Educação Científica, essas discussões ajudaram na criação de áreas como a de Ciência, Tecnologia e Sociedade, bem como alimentar vastos programas de pesquisa em que se investigam as concepções sobre natureza da ciência de estudantes, docentes, em materiais didáticos, etc. Acontece que as críticas sobre uma pretensa objetividade científica eram feitas ainda dentro de um modelo de ciência que perpetuava a supremacia branca.

Por supremacia branca, estamos nos referindo a um sistema sócio-político e econômico em que a alocação das posições de prestígio na sociedade, de poder na tomada de decisões que atingem a população e a concentração de bens financeiros encontra-se, desproporcionalmente, nas mãos de pessoas brancas. Além disso, esse modelo se auto-regula para que continue havendo a manutenção das vantagens da população branca. A Educação Científica, nos moldes em que a conhecemos, acaba sendo um instrumento de manutenção desse sistema opressor.

As formas em que a Educação Científica contribui para a consolidação de uma supremacia branca são diversas. Ao omitir a diversidade de formas de construção de conhecimento, privilegiar uma racionalidade eurocêntrica e não promover produções científicas realizadas por pessoas negras, indígenas e de outros grupos étnico-raciais marginalizados, a educação em ciências é instrumento de manutenção de visões eurocêntricas do conhecimento. Um espaço escolar que supervaloriza os trabalhos feitos por um grupo racial e diminui ou omite o que é feito por outros grupos, não se torna propício para o desenvolvimento de identidades científicas (ROSA, 2013). E, se concordarmos com estudos 
que mostram a importância de que estudantes se identifiquem com as ciências para que ocorra a aprendizagem (ROSA, 2019), então uma educação em ciências em um país de maioria negra, que não contempla conteúdos que valorizem produções científico-tecnológicas negras está, deliberadamente, comprometendo as condições de aprendizagem da maior parte do alunado.

Voltemos à definição do dicionário Oxford para a expressão pós-verdade: é conjunto de circunstâncias em que fatos objetivos são menos influentes na formação da opinião pública do que, por exemplo, o apelo à emoção e às crenças pessoais. Ao olharmos para conceitos e conteúdos presentes em nossos processos de escolarização, particularmente em ciências, podemos observar a existência de fatos produzidos que contrariam fatos objetivos e, por influência de emoções e crenças pessoais, foram amplamente divulgados e tomados como verdades.

Essas verdades não são absolutas ou dogmáticas, são entendidas como construtos passíveis de alteração conforme apontem evidências científicas, em visões mais objetivistas da ciência. Em uma perspectiva sociológica, pode-se considerar que essas verdades serão alteradas quando pessoas socialmente creditadas como cientistas definirem, coletivamente, que deve ou não haver mudanças. $\mathrm{O}$ estatuto das verdades científicas de nossa escolarização está sujeito à discussão e tem sido debatido no âmbito das investigações que questionam a natureza da ciência. Entretanto, os questionamentos não nos permitem sair da esfera dos fatos produzidos de forma a esconder os fatos objetivos; as discussões permanecem nos limites da ciência eurocêntrica.

É necessário, portanto, que esses limites sejam rompidos e, num processo de giro decolonial, fatos objetivos sejam recuperados e trazidos para compor o currículo da educação científica. Esse é um amplo programa de pesquisa que deve ser estabelecido em nossa comunidade. Embora existam poucos trabalhos que façam um resgate de fatos objetivos que foram escondidos pela ciência racista, há produções que nos permitem não partir do zero. No Brasil, os trabalhos de Henrique Cunha Júnior, intelectual negro, engenheiro, professor da Universidade Federal do Ceará são exemplos de resgate de saberes, entendidos como pertencentes à esfera científico-tecnológica, de produção negra. Para além do resgate, Cunha Jr. denuncia a apropriação, pela academia branca, do conhecimento produzido por corpos negros.

Retomando o século XVI, Cunha Jr. (2010) chama atenção para o fato de que a colonização do Brasil pelo povo português se deu através de processos do tráfico de pessoas negras do continente africano e escravização de seus trabalhos. A produção agrícola de culturas tropicais que foi desenvolvida no Brasil não era de domínio de Portugueses, mas era comum a várias regiões do continente africano. Assim, a fonte de conhecimento da base técnica e tecnológica necessária no Brasil foi proveniente das pessoas negras escravizadas. Embora os fatos produzidos em relação à mão de obra forçada de pessoas negras sejam de que os colonizadores ensinavam os trabalhos aos escravizados, pouco dotados de inteligência, e 
que tinham como único valor a capacidade física braçal é mentirosa e sem sentido. Como dominariam, os europeus, as técnicas e tecnologias relativas ao cultivo de cana-de-açúcar, café, banana, algodão, arroz e amendoim? Essas eram agriculturas tropicais bastante desenvolvidas em regiões africanas antes do século XVI, além de "produtos como açúcar e tecidos" (CUNHA JR. 2010, p.12). A produção de açúcar e tecidos requer conhecimento de tecnologias de manufatura da cana-de-açúcar e do algodão, o que indica um saber de transformação, de ciência aplicada. Os fatos produzidos que reduzem as capacidades de corpos negros a serviços braçais e desprovidos de intelectualidade não se sustentam à análises, nem tão complexas, quando olhamos para os fatos históricos do continente africano.

A transformação de matéria-prima em produtos que requerem domínio de ciência dos materiais é também vista nos processos da mineração no Brasil. Durante o período colonial, o principal produto da mineração era a produção, em grande escala, de ouro.

Vejam que a escala de produção não implica apenas a abundância do produto, mas também as formas técnicas da sua extração. A mina de grandes proporções, mesmo que a céu aberto, faz parte de um conhecimento específico. a mineração na mesma forma e na mesma escala da brasileira já era realizada em pelo menos duas regiões africanas, da África ocidental e da região de Zimbábue. o periodo do ciclo do ouro no Brasil foi um periodo de muita inovação de técnicas, graças à base de conhecimento africano transferida para o Brasil. A exploração muitas vezes não se restringe à mineração, mas também à fundição, às profissões de ourives e à produção de joalheria (CUNHA JR., 2010, p. 23).

É importante trazer essa contextualização do período colonial para evidenciarmos parte das estratégias que fizeram e fazem parte dos processos de desumanização de corpos negros, pilhagem epistêmica, construção e consolidação de imagens sobre pessoas negras que informam o ensino e a divulgação científica. Essas imagens solidificam visões de que pessoas negras são sub-humanas, por isso menos importantes, por isso passíveis de serem mortas, contribuindo para que educadoras e educadores acabem por minimizar a importância do racismo contra pessoas negras em suas práticas educativas ou pesquisas acadêmicas. Outro aspecto disso é o fortalecimento de noções de que pessoas negras são desprovidas de intelectualidade, capacidades cognitivas complexas, ou pensamentos de alta ordem, portanto não capazes de produzir conhecimento matemático, científico e tecnológico.

Esse conjunto de concepções sobre pessoas negras alimenta a opinião pública, de modo geral, e a comunidade de ensino e divulgação científica, em particular, criando um terreno favorável para que fatos produzidos dentro de um contexto de racismo antinegro sejam facilmente assimilados. Tudo isso não se dá da noite para o dia, é um processo longo, de séculos. Não se pode minimizar o fato objetivo de que o período de escravidão legalizada no Brasil durou quase 400 anos e que ainda hoje, em 2020, ocorra situações de pessoas negras que são mantidas em condições de trabalho análogas à escravidão. Portanto, os efeitos dessa 
construção de visões negativas sobre pessoas negras são ainda presentes e fortes, permeando todos os espaços sociais, incluindo-se escolas, universidades e centros de produção científica.

As construções racistas antinegro não se iniciam nos períodos de colonização e, portanto, influenciam a ciência eurocêntrica independentemente dos fatos que trazemos sobre a técnica e tecnologia africana no período colonial brasileiro. Van Sertima (2003) compila e analisa evidências que registram construções de embarcações por povos africanos e a travessia do oceano Atlântico ao continente americano antes do período das chamadas grandes navegações europeias. O historiador Pedro Mártir d'Anglería fez os primeiros relatos de que se têm notícia sobre a exploração das Américas, em seu De Orbo Novo (Sobre o Mundo Novo), de 1530, (D'ANGLERIA, 2004). Nesse livro, o autor descreve o encontro de espanhóis com africanos que já viviam na região, em Quarequa (atual Panamá), e atribui a presença de africanos a, provavelmente, acidentes com embarcações piratas naquela região montanhosa ${ }^{7}$. Van Sertima analisa que a presença de africanos no continente não foi acidental, mas planejada e com trocas de frutas, grãos e artesanato entre os continentes.

Resgatar e expor fatos produzidos não se faz sem críticas e quando a base do negacionismo dos fatos objetivos é o racismo antinegro, mais difícil é de se trazer os fatos objetivos para o debate. Existem várias teorias sobre presença no continente americano antes de Colombo e após a pré-história. Entretanto, uma das teorias mais aceitas é de uma presença nórdica (CORDELL et al., 2008), enquanto a de presença africana recebe duras críticas como a de Haslip-Viera, De Montellano e Barbour (1997), que também questionam as teses de Diop sobre a população egípcia ser negra. O próprio Cheikh Anta Diop, embora formado em filosofia e química pela Sorbonne, tendo recebido seu doutorado sob a orientação de Gaston Bachelard, como já mencionamos, e se especializado em física nuclear com Frédéric JoliotCurie, é pouco conhecido da comunidade em educação científica. Apesar de sua invejável formação e propriedade no trabalho realizado, o intelectual senegalês teve grande dificuldade na aceitação de suas pesquisas que evidenciam a população do Egito como sendo negra. Que outras razões para esse negacionismo que não o apelo às emoções oriundas de um racismo antinegro?

Podemos continuar nosso passeio pela história e evidenciar outros momentos em que a ciência construiu fatos que foram amplamente aceitos e disseminados, contrariando fatos objetivos, simplesmente em função de um racismo antinegro. Aristóteles, personagem da Grécia que muito influenciou a educação em ciências, particularmente o ensino de física, nasceu em 384 a.C., foi discípulo de Platão e, aos 41 anos, foi ser tutor de Alexandre, que se

\footnotetext{
${ }^{7}$ D'Angleria escreve "The Spaniards found negro slaves in this province. They only live in a region one day's march from Quarequa, and they are fierce and cruel. It is thought that negro pirates of Ethiopia established themselves after the wreck of their ships in these mountains. The natives of Quarequa carry on incessant war with these negroes. Massacre or slavery is the alternate fortune of the two peoples." Vale informar que, "etíopes" eram chamados africanos em geral, não necessariamente da região da Etiópia e "escravos", nesse caso, não eram africanos escravizados trazidos por europeus ao continente americano, e sim "presos de guerra" de conflitos entre diferentes grupos, como explica Van Sertima (2003, p. 24). Aqui, os conflitos eram entre indígenas e africanos que já habitavam o continente americano.
} 
tornou imperador. James (1992) argumenta que a imigração de Gregos para o Egito para fins de educação se iniciou como resultado da invasão Persa e continuou até que os Gregos, através de Alexandre, o Grande, conseguiram a posse daquelas terras e acesso à biblioteca Real. Como prática comum no período, invasores saqueavam tesouros de terras invadidas, tais como ouro, joias e livros. Nesse momento, Alexandre, o Grande, presenteia Aristóteles com livros saqueados do Egito (JAMES, 1992). Aos 49 anos de idade, em 335 a.C, Aristóteles retorna a Atenas e, entre 335 a.C. e 323 a.C., nos seus 50 anos, é quando realiza a maior parte de seu trabalho que, hoje, conhecemos. Apesar das várias décadas sob a tutela de Platão, é somente após o contato com o conhecimento saqueado do Egito que Aristóteles compartilha seus famosos pensamentos. James (1992) sugere e discute evidências para sustentar que não apenas Aristóteles foi fortemente influenciado pela produção intelectual do Egito, mas a filosofia grega, de modo geral, tem bases não creditadas ao que se tinha no país africano.

Para evidenciarmos outros fatos produzidos no contexto da histórica pós-verdade da supremacia branca, da ciência eurocêntrica, trazemos mais exemplos (Fig. 1 e 2) de fatos produzidos que se sustentaram ao longo da história, no lugar de fatos objetivos, em função das emoções que motivaram uma opinião pública baseada em racismo antinegro.

A "pirâmide da pós-verdade" sinaliza essa estrutura das construções de alguns conhecimentos. As pirâmides A e B evidenciam movimentos de apagamento histórico de produções e feitos realizados no continente africano, como o domínio da navegação transatlântica e o reconhecimento de que povos egípcios eram negros. A pilhagem feita pelos gregos de construções matemáticas egípcias está disposta na pirâmide $\mathrm{C}$, ao lembrar que a relação matemática do teorema do quadrado da hipotenusa, conhecida por "Teorema de Pitágoras", foi amplamente utilizada por africanos, hindus, babilônios e chineses, antes do nascimento do grego Pitágoras. Pitágoras provavelmente aprendeu a relação matemática quando morou e estudou no Egito, aos 22 anos (SILVA, p. 58).

A Fig. 2 traz outros exemplos de construções de pós-verdades ao longo da história, a partir de um pensamento hegemônico eurocêntrico. As dicotomias construídas durante o colonialismo, como moderno versus primitivo, civilizado e não civilizado, a partir do referencial europeu colonizador universal versus povos colonizados, foram estendidas aos sistemas epistemológicos. Assim, sistemas de conhecimentos de povos originários são "primitivos", não civilizados, e "pré-científicos"; fazem parte de uma "pré-verdade" (pirâmide D). Entretanto, povos originários brasileiros, por exemplo, possuem sistemas de conhecimentos completamente integrados aos aspectos ecológicos, meteorológicos, cosmológicos e astronômicos (LIMA et al. 2013); compartilham de sistemas epistemológicos complexos, desenvolvendo tecnologias preditivas, não exploratórias e com respeito à conservação da biodiversidade - o que consideramos bem mais "civilizado" do que as práticas da ciência moderna. 


\section{Construção de pós-verdades}
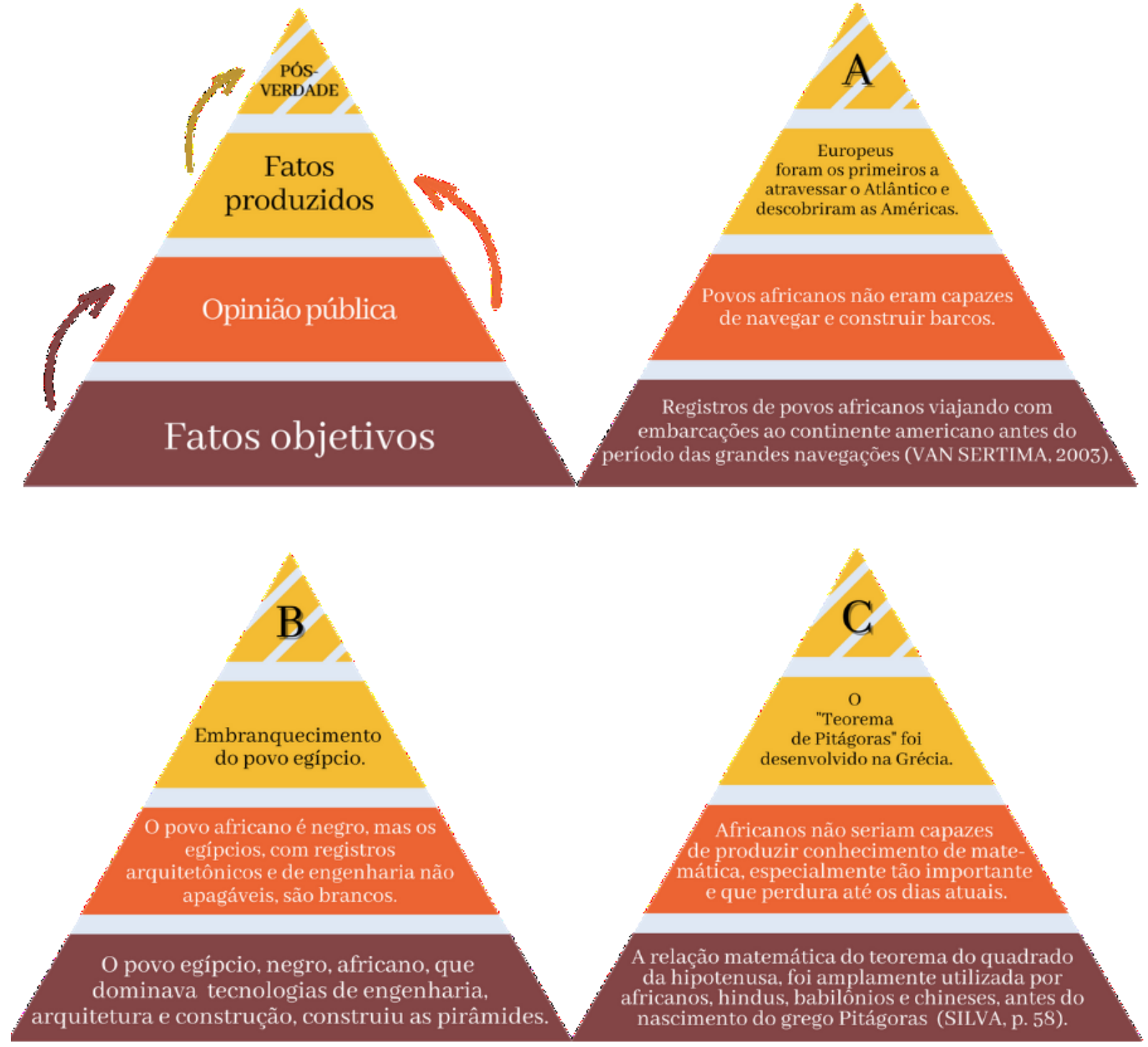

Fig. 1 - Exemplos de construções de pós-verdades ao longo da história.

Fonte: As autoras.

A ideia de que astronomia nasce na Grécia ignora os conhecimentos produzidos por povos babilônios, assírios e egípcios, que tinham conhecimentos sobre calendários baseados em movimentos celestes. Egípcios, por exemplo, adotaram um calendário baseado em um ano de 365 dias e tinham registros dos movimentos da estrela Sirius, que correspondia a um ciclo anual das enchentes do rio Nilo (FRAKNOI et al., 2016). Os povos chineses também tinham calendários e registros de cometas, meteoros e pontos escuros na superfície solar (FRAKNOI et al., 2016). O povo Dogon, na região do Mali, têm há séculos transmitido oralmente conhecimentos precisos sobre objetos do Sistema Solar (luas de Júpiter e anéis de Saturno), sobre a estrela Sírius e sobre a morfologia da Via-Láctea (VAN SERTIMA, 1983). Os povos Maias construíram dispositivos que possibilitaram a observação e documentação de 


\section{Construção de pós-verdades (cont.)}

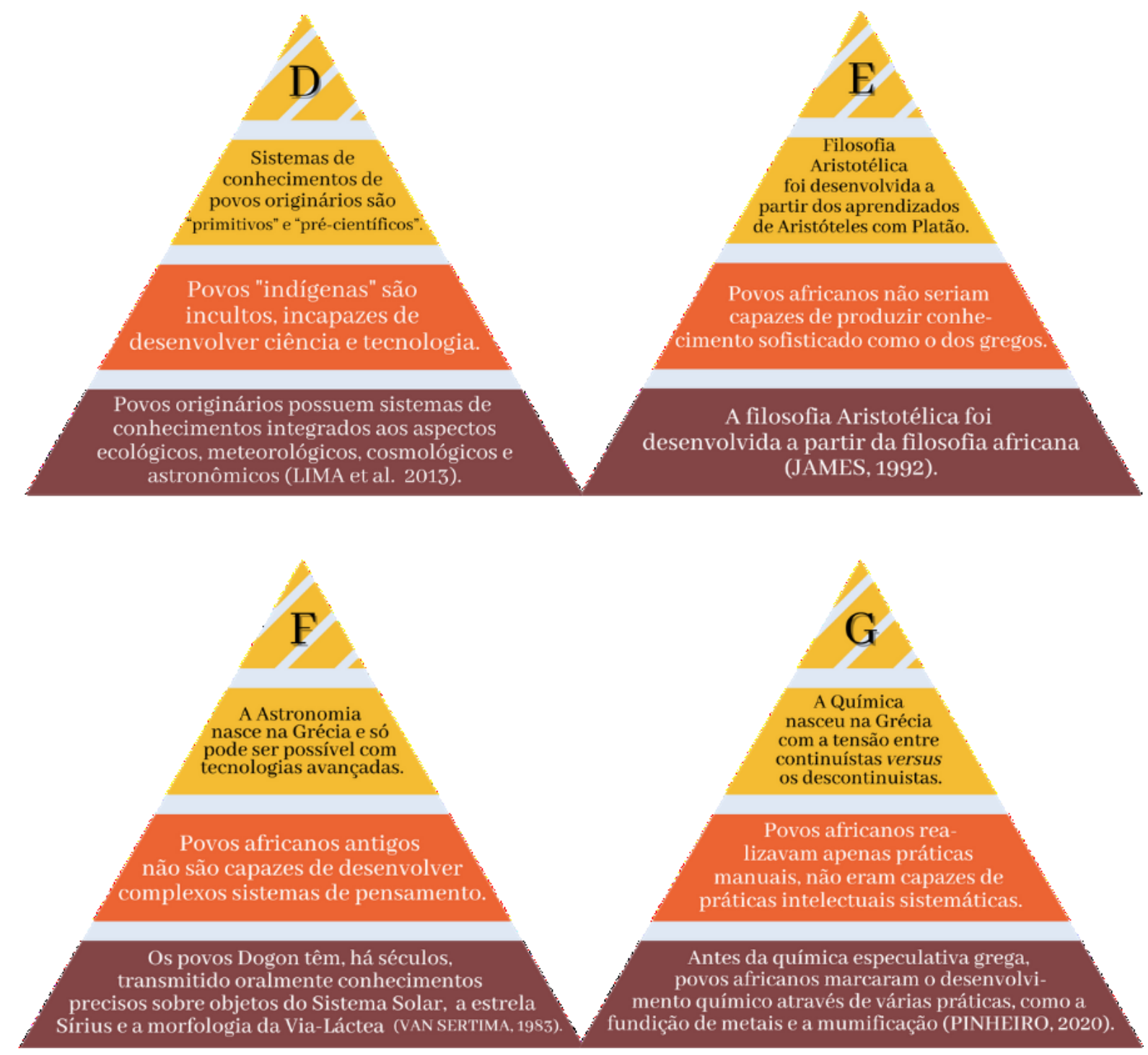

Fig. 2 - Fatos produzidos, fatos objetivos e influência da opinião pública.

Fonte: As autoras.

movimentos de corpos celestes, o que os levou a construção dos calendários Maia (COOK, 2018). Dessa forma, a noção de que todo conhecimento sobre o Sistema Solar e, principalmente, sobre a morfologia da Via-Láctea, só pode ser possível com tecnologias avançadas é mais um produto da pós-verdade.

Outra forma que a colonialidade utiliza para estabelecer a supremacia eurocentrada é a desqualificação da produção intelectual de povos não europeus. A história que nos é contada através dos livros didáticos na escola é a de que a química nasceu na Grécia com a tensão continuístas (Heráclito, Parmênides, Anaxímenes, Tales de Mileto, etc.) que acreditavam na teoria do elemento originante, versus os descontinuistas (Leucipo, Demócrito e Epicuro) que 
defendiam a hipótese atômica. Entretanto, dentro da protoquímica, há um período anterior a química especulativa grega que é marcado pelo desenvolvimento químico de papiros, cerâmica, bebidas alcoólicas, cosmetologia, tinturaria, fundição de metais e pela prática mais fascinante da química ancestral africana: a mumificação (PINHEIRO, 2020). Essas técnicas e conhecimento sistematizado são ensinados, nos conteúdos escolares, apenas como práticas manuais, no máximo chamadas de técnicas, desqualificando o trabalho intelectual envolvido.

Voltando ainda mais, temos em 1600 a.C. o registro do papiro de Edwin Smith (Fig. 1), o mais antigo texto da medicina Kemetiana. Esse documento é tido como o único dos primeiros papiros médicos que tem uma abordagem científica; é um tratado médico que descreve ferimentos, anatomia e tratamento de medula espinhal (HUGHES, 1988). Pensemos, por um segundo, na complexidade de um tratado médico que fala sobre a medula espinhal e que tem reconhecimento da academia branca de ter uma abordagem "científica". Há controvérsias sobre a autoria do papiro, que pode ter sido escrito pelo egípcio Imhotep. Não há controvérsias, entretanto, sobre o nome que o documento ganhou: o de um estadunidense que tinha em suas posses pessoais um documento de tal magnitude histórica.

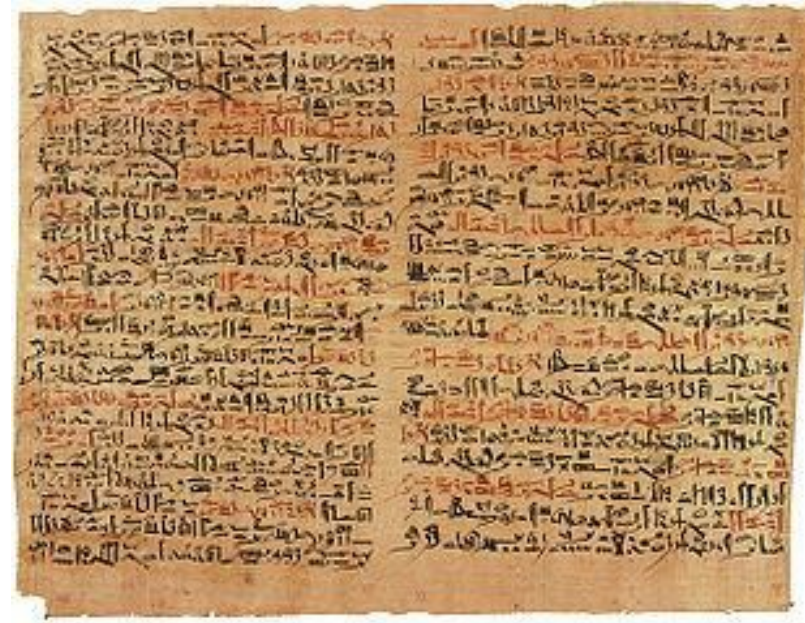

Fig. 3 - Papiro de Edwin Smith (1600 a.C.) antigo texto da medicina egípcia.

Fonte: Wikimedia Commons.

Ao finalizarmos esse texto com a imagem do papiro de "Edwin Smith" (Fig. 3), um tesouro de Kemet e da humanidade, lembramos que o documento não se encontra no Egito, onde deveria estar, mas na Academia de Medicina de Nova York, cidade símbolo do capitalismo "moderno", o capitalismo que se entrelaça e se sustenta com o racismo antinegro, violentando corpos e mentes de povos negros de África e da diáspora.

Reconhecemos que existe um movimento negacionista. Há um negacionismo da extensão do racismo e seus efeitos em nossa sociedade. Como pontua Perosa (2017), ao discutir a pós-verdade, não basta expor uma pessoa a informações que questionem suas crenças, ou seja, contrárias às suas visões de mundo, nesses casos, as chances de que ela mude de opinião ou aceite dados novos como fatos são muito baixas. A assimilação dos fatos 
produzidos acontece por todas as pessoas, brancas e não-brancas. Isso significa que a própria população negra, vítima de práticas da supremacia branca, num vil processo psicológico ${ }^{8}$ que estimula o auto-ódio, também compartilhará a opinião de que corpos negros são menos importantes e de menor intelectualidade. O mecanismo racista de uma construção cultural que inferioriza as populações negras é o que permite o sucesso do racismo no Brasil e em outras partes do mundo. Assim, o trabalho de resgate de saberes africanos e afrodiaspóricos, a valorização de corpos e mentes negras é uma tarefa necessária a todas as pessoas, negras e não-negras. A importância da valorização intelectual negra é para além de um enfrentamento de uma pós-verdade eurocêntrica, é também uma questão de reparação histórica e compromisso de uma sociedade que queira, de fato, buscar equidade racial.

\section{Implicações para o Ensino de Física}

Considerando o compromisso para equidade racial, a necessidade de valorização intelectual negra e o papel da educação científica, gostaríamos de ressaltar algumas implicações dessa discussão para o ensino de física, de forma mais específica, e os compromissos práticos e teóricos que acreditamos que nossa comunidade deva assumir. Enquanto educadoras e educadores em física, devemos nos questionar como é possível que, em um país que tem uma maioria de população estudantil negra na educação básica não consigamos promover um engajamento científico desse grupo racial na física. Enquanto estudantes negras e negros são maioria nas universidades federais (ALFANO; TATSCH; CAPETTI, 2019), nossas experiências enquanto docentes de cursos de física sugerem que o número de estudantes de física negras e negros não esteja acompanhando os números gerais do nível superior. Qual será o papel que a colonialidade, manifestada através da pilhagem epistêmica e apagamento das contribuições negras (e de povos originários) nas áreas de ciência e tecnologia, tem nesse processo? Essa pergunta, por si só, deveria estar em projetos de pesquisa na área de ensino de física.

Entendemos que questionar as verdades estabelecidas dentro da colonialidade pode ser feito de diversas formas, tais como:

decolonial;

a) revisão dos conteúdos escolares de física, a partir de uma perspectiva

b) inclusão de uma história e filosofia da ciência que considere marcadores conceituais para além dos produzidos pelo Norte-Global, oferecendo uma pluralidade de visões epistêmicas, a fim de se quebrar a noção de que existe apenas um referencial epistêmico válido;

c) reconhecimento da heterogeneidade de formas e conteúdos, o que perpassa em valorizar, por exemplo, produções baseadas em metodologias centradas na oralidade;

\footnotetext{
${ }^{8}$ Para uma discussão mais aprofundada em relação aos efeitos psicológicos do racismo anti-negro nas pessoas negras, sugerimos o livro Peles negras, máscaras brancas, de Frantz Fanon.
} 
d) inclusão de biografias e personagens negras, contemporâneas e da antiguidade, que produzem conhecimentos científicos ${ }^{9}$, numa perspectiva que promova, em estudantes negras e negros, uma construção de identidade positiva em relação à ciência e em demais estudantes, uma visão positiva sobre as intelectualidades de pessoas negras;

e) revisar teorias e métodos de ensino-aprendizagem que foram pautados, pesquisados e testados não apenas sob um referencial eurocêntrico de racionalidade, mas que produziram dados de pesquisa com sujeitos pouco diversos, não representantes da população estudantil, como mostra recente pesquisa que olhou para as produções da área de pesquisa em ensino de física (KANIM, CID, 2020) - e são essas teorias e métodos que utilizamos cotidianamente na comunidade de ensino de física.

Essas considerações são válidas tanto para o ensino escolar de física, quanto para a formação docente e para a pesquisa em ensino de física. As mudanças precisam ocorrer em várias frentes e esferas.

\section{Considerações finais}

Esperamos que este texto tenha fornecido elementos para que a comunidade de educação e divulgação científica passe a repensar suas preocupações com a pós-verdade, enquanto um fenômeno decorrente da crítica à ciência moderna construída por estudiosos nos séculos XX e XXI. Mais do que isso, que o debate aqui proposto contribua para que se questionem as emoções e visões que promovem a manutenção de um sistema de crenças pronto para deslegitimar o pensamento de alteridades negras, esse sim, por nós entendido como uma pós-verdade. Este ensaio questionou a universalidade e supremacia branca científica, disponibilizou discussões para que a educação em ciências possa ser repensada, a partir de uma perspectiva decolonial, antirracista e trouxe exemplos concretos de como nosso ensino de ciências se configura num estado de negacionismo de produção científicointelectual proveniente de povos negros.

Por fim, queremos enfatizar que, historicamente, na base da construção das narrativas modernas da ciência e da tecnologia, sempre houve um sistema de crenças pronto para esvaziar de sentido de pensamento as alteridades negras, hierarquizando as raças e fomentando as desigualdades étnico-raciais e sociais, não apenas nos processos de produção de ciência, mas, sobretudo, em suas relações de educação e comunicação. Os sistemas de verdade do mundo moderno, que têm implicações diretas no processo de se educar e comunicar ciências em nossos tempos são completamente colonizados, baseados na divisão entre raças em que negros e indígenas são estrangeiros do pensamento, permanecendo como corpos subalternizados, expatriados do território colonizado. Para Fanon, “A impugnação do

\footnotetext{
${ }^{9}$ Mesmo dentro das métricas do que temos, hoje, socialmente aceito como ciências físicas. Isso significa que, ao contrário do que se pode pensar, uma abordagem decolonial para o ensino de física não irá, necessariamente, destruir o que se compreende como física, mas abrir possibilidades para ampliar as formas humanas de produzir conhecimento no mundo.
} 
mundo colonial pelo colonizado não é um confronto nacional de qualquer ponto de vista. Não é um discurso sobre o universal, mas a afirmação desenfreada de uma originalidade formulada como absoluta" (FANON, 1961, p. 36). Esse sistema de crenças da civilidade e racionalidade do colonizador termina por desumanizar, animalizando os colonizados. Para Fanon não haveria qualquer outra solução senão expulsar os estrangeiros do território. Para isso, é necessário visibilizarmos intelectuais negras e negros e usarmos novas epistemologias de produção de conhecimento, reconhecendo a contribuição histórica de povos que foram colocados num estado de negação de conhecimento, como se fossem sempre um produto da "pós-verdade".

\section{Referências}

ADICHIE, C. O perigo de uma história única. 1. ed. São Paulo: Companhia das Letras. 2018.

ALFANO, B.; TATSCH, C.; CAPETTI, P. Negros são maioria pela primeira vez nas universidades públicas, aponta IBGE. O Globo. 2019. Disponível em: $<\underline{\text { https://oglobo.globo.com/sociedade/educacao/negros-sao-maioria-pela-primeira-vez-nas- }}$ universidades-publicas-aponta-ibge-24077731>. Acesso em 30/08/2020.

ALVES-BRITO, A.; MASSONI, N. T; GUERRA, A; MACEDO, J. R. Histórias (in)visíveis nas ciências. I. Cheikh Anta Diop: um corpo negro na Física. Revista da ABPN, v. 12, n. 3, 290, dez 2019 - fev 2020.

ALVES-BRITO, A. Os Corpos Negros: questões étnico-raciais, de gênero e suas intersecções na Física e na Astronomia brasileira. Revista da ABPN, 2020, aceito.

ANDERY, M. A.; MICHELETTO, N.; SÉRIO, T. M. P.; RUBANO, D. R.; MOROZ, M.; PEREIRA, M. E.; GIOIA, S. C.; GIANFALDONI, M.; SAVIOLI, M. R.; ZANOTTO, M. de L. Para compreender a ciência: uma perspectiva histórica. 16. ed. Rio de Janeiro: Garamond, 2012.

ANI, M. Yurugu: An African-Centered Critique of European Cultural Thought and Behavior. Trenton: Africa World Press, 1994.

ANTENEODO, C.; BRITO, C.; ALVES-BRITO, A.; ALEXANDRE, S. S.; D’AVILA, B. D.; MENEZES, D. P. Brazilian physicists community diversity, equity, and inclusion: A first diagnostic. Physical Review Physics Education Research, v. 16, 010136, 2020. 
ARENDT, H. O Pensamento racial antes do racismo. In: ARENDT, H. Origens do totalitarismo. Tradução: Roberto Raposo. São Paulo: Companhia das Letras. 1998.

BETHENCOURT, F. Racismos: das cruzadas ao século XX. São Paulo: Companhia das Letras, 2018.

CARnEIRO, S. A Construção do Outro como Não-Ser como fundamento do Ser. 2005. 339f. Tese (Doutorado em Educação) - Faculdade de Educação da Universidade de São Paulo, São Paulo.

CÉSAIRE, A. Discurso sobre el colonialismo. Madrid: EdicionesAkal, 2006.

COOK, J. 7 Ancient Cultures and How They Shaped Astronomy. Office of Astronomy for Development. 26 nov. 2018. Disponível em: <http://www.astro4dev.org/blog/2018/11/26/7ancient-cultures-and-how-they-shaped-astronomy-guest-blog/>. Acesso em: 30 ago 2020.

CORDELL, L.; LiGHTFOOT, K.; McMANAMON, F.; MILNER, G. Archaeology in America: An Encyclopedia. 2008. ABC-CLIO. p. 82-83. ISBN 978-0-313-02189-3.

CUNHA JÚNIOR, H. Tecnologia africana na formação brasileira. Rio de Janeiro: CeaP, 2010. 52p.

D'ANGleriA, P. M. De Orbe Novo. Tradução: Francis Augustus MacNutt. Publicação original, 1530. Edição Projeto Gutenberg, 2004.

DIOP, C. A. A origem dos antigos egípcios. IN: MOKHTAR, G. (Org). História Geral da África: A África antiga. São Paulo: Ática/ UNESCO, 1983. p. 39-70.

DUSSEL, E. 1492: o encobrimento do outro. A origem do "mito da modernidade". São Paulo: Vozes, 1993.

ENGLISH OXFORD DICTIONARIES. World of the Year 2016. Disponível em: $<$ https://languages.oup.com/word-of-the-year/2016/>. Acesso em: 10 jun 2020.

FANON, F. Os Condenados da Terra. Rio de Janeiro: Editora Civilização Brasileira, 1961.

FANON, F. Pele Negra Máscaras Brancas. Tradução: Renato Silveira. Salvador: EDUFBA, 2008.

FINCH III, C. S. A Afrocentricidade e Seus Críticos. In: NASCIMENTO, E. L. (Org.). 
Afrocentricidade: Uma abordagem epistemológica inovadora. São Paulo: Selo Negro, 2009.

FRAKNOI, A.; MORRISON, D.; WOLFF, S. C. Astronomy. Houston, Texas: OpenStax, 2016. Disponível em: <https://openstax.org/books/astronomy/pages/2-2-ancient-astronomy>. Acesso em: 30 ago. 2020.

FREITAS, H. O arco e a arkhé: ensaios sobre literatura e cultura. Salvador: Oguns Toques Negros, 2016.

G1 Rio. Governo do RJ confirma a primeira morte por coronavírus. G1 Rio, 19 mar 2020. Disponível em: $\quad \leq$ https://g1.globo.com/rj/rio-de-janeiro/noticia/2020/03/19/rj-confirma-aprimeira-morte-por-coronavirus.ghtml >. Acesso em: 12 jun. 2020.

GONZALEZ, L. A categoria político-cultural de amefricanidade. Tempo Brasileiro, Rio de Janeiro, n. 92/93 (jan./jun.), p. 69-82, 1988.

HASLIP-VIERA, G.; DE MONTELLANO, B.; BARBOUR, W. Robbing Native American Cultures: Van Sertima's Afrocentricity and the Olmecs. Current Anthropology, v. 38, n. 3, p. 419-441, 1997. Disponível em: <www.jstor.org/stable/10.1086/204626>. Acesso em: 20 jun. 2020.

HUGHES, J. T. The Edwin Smith Surgical Papyrus: An analysis of the first case reports of spinal cord injuries. International Medical Society of Paraplegia, v. 26, p.71-82, 1988. Disponível em: $<$ https://www.nature.com/articles/sc198815.pdf?origin=ppub $>$ Acesso em: 21 jun. 2020.

JAMES, G. G. M. Stolen legacy: Greek philosophy is stolen Egyptian philosophy. Trenton, NJ: Africa World Press, 1992. 190p.

KANIM, S.; CID, X.C. Demographics of physics education research. Physical Review Physics Education Research, v. 16, 020106, 2020.

LATOUR, B. Imaginer les gestes-barrières contre le retour à la production d'avant-crise. AOC - Analyse Opinion Critique, 31 mar 2020. Disponível em: $\leq$ https://aoc.media/opinion/2020/03/29/imaginer-les-gestes-barrieres-contre-le-retour-a-laproduction-davant-crise $>$ Acesso em: 28 mai. 2020.

LATOUR, B.; WOOLGAR, S. A Vida de Laboratório: a produção dos fatos científicos. Rio de Janeiro: Relume Dumara, 1997. 
LIGHTMAN, B. A Companion to the history of science. John Wiley \& Sons Ltda, 2016.

LIMA, F. P. et al. Astronomia indígena - relações céu-terra entre os indígenas no Brasil: distintos céus, diferentes olhares. In: MATSUURA, O. T. (Org.). História da astronomia no Brasil (2013). Recife: CEPE, v. 1, p. 87-131, 2014.

MATTHEWS, M. R. História, Filosofia e Ensino de Ciências: A tendência atual de reaproximação. Caderno Catarinense de Ensino de Física, v. 12, n. 3, p. 164-214, 1995.

MBEMBE, A. Crítica da Razão Negra. São Paulo: Antígona, 2018.

MELO, A. Biodiversidade: narrativas, diálogos e entrelaçamento de saberes da comunidade/escola em um território quilombola do semiárido baiano. 2019. Tese (Doutorado em Ensino, Filosofia e História das Ciências) - Universidade Federal da Bahia/Universidade Estadual de Feira de Santana, Salvador.

MUNANGA, K. Negritude, usos e sentidos. 4. ed. Belo Horizonte: Autêntica, 2019.

MUNANGA, K.; GOMES, N. O negro no Brasil de hoje. São Paulo: Global, 2006.

NASCIMENTO, A. O genocídio do negro brasileiro: processo de um racismo mascarado. São Paulo: Perspectivas, 2016.

NASCIMENTO, E. L. Sakhu Sheti: Retomando e Reapropriando um Foco psicológico Afrocentrado In: NASCIMENTO, E. L. (Org.) Afrocentricidade: Uma abordagem epistemológica inovadora. São Paulo: Selo Negro, 2009, p. 277-297.

NJERI, A. Educação afrocêntrica como via de luta antirracista e sobrevivência na maafa. Revista Sul-Americana de Filosofia e Educação, n. 31, p. 4-17, mai.-out./2019. DOI: $<$ https://doi.org/10.26512/resafe.vi30.28253 $>$.

ONION, A.; SUlliVAN, M.; MULlEN, M. Mayan Scientific Achievements. History. A\&E Television Networks. 17 mai. 2010. Disponível em: $<$ https://www.history.com/topics/ancientamericas/mayan-scientific-achievements $>$. Acesso em: 18 jun. 2020.

PINHEIRO, B. O período das artes práticas: a Química ancestral africana. Revista Debates em Ensino de Química, v. 6, n. 1, 2020. Disponível em:

$<$ http://www.journals.ufrpe.br/index.php/REDEQUIM/article/view/3566. Acesso em: 20 jun 
2020.

QUIJANO, A. Colonialidade do poder, eurocentrismo e América Latina. In: LANDER, E. (Org.). A colonialidade do saber: eurocentrismo e ciências sociais. Buenos Aires: Consejo Latinoamericano de Ciencias Sociales - CLACSO, 2005. p. 345-392.

ROSA, K. Gender, Ethnicity, and Physics Education: Understanding How Black Women Build Their Identities as Scientists. 2013. 191f. Tese (Doutorado em Educação Científica) Columbia University, New York.

ROSA, K. Race, Gender, and Sexual Minorities in Physics: Hashtag Activism in Brazil. In: PIETROCOLA, M. (Org). Upgrading Physics Education to Meet the Needs of Society. Switzerland: Springer, 2019. p. 221-238.

SANTAELlA, L. A Pós-Verdade é Verdadeira ou Falsa? Barueri, SP: Editora estação das letras e cores, 2018. 96p.

SANTOS, B. de S.; MENESES, M. P. (Org.). Epistemologia do Sul. São Paulo: Cortez, 2010.638p.

SCHWARCZ, L. K. M. Commentary: Brazil as a Continuous Laboratory of Races. American Anthropologist, v. 116, p. 1-2, 2014.

SILVA, G. R. Uma proposta didática para descolonizar o "Teorema de Pitágoras" em cursos de licenciaturas em matemática. In: PINHEIRO, B. S.; ROSA, K. (Org.). Descolonizando saberes: a Lei 10.639/2003 no ensino de ciências. São Paulo: Editora Livraria da Física, 2018. Cap. 3. p. 57-74.

SPIVAK, G. Pode o subalterno falar? Belo Horizonte: Editora UFMG, 2010.

TESICH, S. A Government of Lies. The Nation, January, 6, 12-14. 1992. Disponível em: $<\underline{\text { https://drive.google.com/file/d/0BynDrdYrCLNtdmt0SFZFeGMtZUFsT1NmTGVTQmc1d }}$ EpmUC1z/view>. Acesso em: 15 jun. 2020.

VAN SERTIMA, I. The lost sciences of Africa: an overview. In: SERTIMA, I. V. (Org.). Blacks in Science: ancient and modern. New Brunswick, Oxford: Transaction Books, 1983.

VAN SERTIMA, I. They came before Columbus: The African presence in Ancient America. New York: Random House Trade Paperbacks, 2003. 284p. 